\title{
Foster Care-Importance of Transition Planning Practice-based Research: An Elaborative, Explorative Approach
}

\author{
Susanne Nef *and Karin Werner ${ }^{\dagger}$
}

\begin{abstract}
Although, foster care is relatively widespread in Switzerland, the professional transition planning of the transfer of decision-making abilities, after the foster children attain the age of majority, is a topic, which has rarely been taken into account so far. However, it is important that transition planning, including all administrative, transfer of decision-making abilities, and guardianship processes, should begin at least one year before the age of majority (the age of consent in Switzerland is 18). Even so, professional transition planning is barely standardised and institutionalised yet. In this practice-based research study the current situation and the perception of the relevant groups, the need of the practice, and foster families have been analysed. Therefore, qualitative data collection methods have been used to focus on a multi-perspective approach, including that on foster parents and social workers at official municipality-level. Several relevant topics and aspects, such as applicable administrative tasks or residential issues, which are considered to be of particular relevance and therefore have to be addressed during the transition
\end{abstract}

\footnotetext{
${ }^{*}$ Research Associate, Department of Social Work, Zürich University of Applied Sciences, Switzerland; susanne.nef@zhaw.ch

† Lecturer, Department of Social Work, Zürich University of Applied Sciences, Switzerland; karin.werner@zhaw.ch
} 
planning process, have been found. Moreover, important emotional and social aspects were identified.

Keywords: Foster care, Care leaving, Transition planning, Practicebased research

\section{Foster Care in Switzerland}

Usually, parents have the responsibility for the care and education of their children. However, for various reasons, they may not be able to take up this responsibility, for instance, due to physical or psychological illness, parenting problems or substance abuse. In cases, where the development of children is potentially at risk, the temporary or long-term accommodation in a children's or youth home or in a foster family is a possible intervention to ensure the child's well-being (Gassmann, 2010, p. 20). Under such imminent circumstances, the municipality level authorities carefully consider what type of home or foster family including its environment is the most appropriate for the placement of such child. These so-called "foreign placements" can be arranged and carried out by the consent of the parents or in the context of civil protection for children or youth and criminal protective interventions even against the will of the parents (Aebischer and Gabriel, 2013, p. 8).

Foster child relationships are temporary. No matter how long a foster child has been living in a foster family, a foster care is always impermanent. It may happen that a foster child, after living with the foster family for a certain time, returns to its family of origin. It could be because of the eventual stabilisation of the situation to a considerable extent back home. However, during the period of foster care, several moments may be crucial and challenging for the foster families. But the most demanding ones might be the moments when the child is entering the foster family and its transition to the age of consent.

Besides the placement, the transition from foster care to selfdependence has to be well prepared and professionally accompanied (Schröer and Severine, 2014). This process of leaving care has a high impact on the further development of foster youth. Studies from European countries show that young adults in particular, leaving their foster home soon after reaching the age of 
majority might have an increased risk of being affected by eventualities such as unemployment, homelessness, or social isolation (Stein and Munro, 2008). Despite these findings, neither the way of supervision and counselling (Zatti, 2005) nor the supervision in this transitional phase is institutionalised in Switzerland. In fact, there is no nationwide child and youth service Act in Switzerland and little research has been carried out on child care and the outcomes of residential and foster care (Gabriel and Stohler, 2008, p. 202).

\section{Practice-based research as an approach of social work research}

The impact of practitioners and service users on social work research is one of the main discourses in this field, whichespecially in Europe-is contemporarily influenced by practicebased and evidence-based research approaches. Both approaches distinguish the intrinsic connection between knowledge, research and practice in social work. Representatives of both approaches argue that the highest standards of social work might be achieved by enhanced appreciation of research.

However, there are significant differences: Evidence-based practice is seen as a process in which the practitioner combines wellresearched interventions with clinical experience to guide and inform the delivery of treatments and services. The practitioner, researcher, and service user must work together in order to identify what works for whom and under what conditions (SWPI, 2010). The approach in practice-based research as well as in evidencebased research is based on a combination of research methodology, field research and practical experience. Both approaches are based on the foundation of practice-based research which means that building theory is not solely based on academics; it also derives from practice (SWPI, 2010; Uggerhøj, 2011). While evidence-based research has been criticized for its hierarchical processes, practicebased research focuses on the heterarchical (horizontal rather than vertical) production of new knowledge and learning strategies on a scientific foundation-mainly in close collaboration with practitioners and researchers by identifying local needs, current 
advantages, and contemporary questions of the practice (Nowotny, Scott \& Gibbons 2001, p. 47).

Nevertheless, within the practice-based research, as part of empirical social research, there are different existing approaches, which differ mainly in the way and intensity of collaboration. Munsch (2012, p. 1178) summarizes three main types of practicebased research: (1) Practice-based research as summative and formative evaluation; (2) practice-based research with the aim to analyse and improve the practice and (3) theory-practice-projects.

\section{Practice-based research project in the field of foster care}

In the following, the presented research project, whose theoretical background and design are based on the research-based practice, is within this framework on theory-practice-projects (Munsch, 2012, p. 1178). Key aspects of this approach are the joint and mutual development of the questions and objectives as well as the joint elaboration of the data collection tools - by researchers and practitioners. Furthermore, the collection and the subsequent processing of data, discussions on the results and their further use are part of mutual and collaborative processes.

The project partner of our practice-based research project is mainly responsible for two subjects: job information centres and child and youth care centres. These centres are providing services in the areas of child support assistance, vocational and career counselling, as well as statutory and voluntary child and youth services in the districts of Hinwil, Meilen, Pfaeffikon, and Uster. The Centre for Foster Families, as one division of our project partner, acts as a regional competence centre, which takes the responsibility to provide expertise, professional knowledge, and supervision of foster care in general, and counselling of social workers, who accompany and counsel foster parents and children.

The role and the tasks of foster parents are very demanding (Jespersen, 2011). Beside the willingness to build a trusting relationship with their foster child and to care, support, and accompany their cognitive, emotional and social development, the foster care contract ends suddenly when the child reaches the age of majority. Nevertheless, many young foster children still live after 
this date with their foster families, often until the end of the formal education and professional training (apprenticeship). Over the years, strong relationships and a supportive community have grown and neither "biological children" nor foster children usually leave automatically their parental home after reaching the age of majority. Therefore, due to the expiration of the foster care contract at this date a number of questions are needed to be clarified for foster parents and foster children. For example: Are both sides willing to continue to live together and if yes, who is going to finance it?

As a remedy for the lack of a concrete instruction manual for providing a standardized and supportive service to empower the social workers and the foster families, a concrete working tool has been developed. This joint theory-practice project has been processed by ZHAW Social Work Department and the Centre for Foster Families. Project participants have developed a working instrument, which is based on the experiences of foster families, social workers, and employees of the Centre for Foster Families.

The practice-based research project adopted an explorative research design, where the perception, perspective, and needs of foster parents were compared with the perspective and professional as well as functional needs of social workers. The aim of the study was to identify and summarize the relevant topics and advantages for foster parents and social workers in context of the transition process. Furthermore, best practices have been evaluated by using semi-structured expert interviews with social workers. Moreover, the perception and needs of foster families have been surveyed by conducting semi-structured narrative interviews. Based on this data, a concrete and standardised research-based working tool and guideline for social workers has been developed.

\section{Main findings}

From the perspective of the respondents, the most important finding is the need to address the transition to adulthood early and to involve all the key actors (foster child, foster family, social workers) in a participatory planning process. Furthermore, many foster parents and foster children are often not aware of the issues 
arising with the 18th birthday of the child. Within the preparation process, it is also important to judge issues concerning emotional and factual matters as related and substantial. Despite the importance of emotional issues, the clarification and responsibility of further financing-especially the childcare allowance-seems to be the most labour-intensive task. The mere fact that teenager rely on a certain amount of care after reaching the age of majority and foster parents therefore continue to receive care benefits is questioned by some authorities repeatedly, shows the importance and the need of clarification in this matter. Moreover, the surveyed foster parents suggest that the professional guidance might not end at the age of majority and emphasize the need of counselling and supervision after this transition period to ensure the individuality of each case within a standardized and institutionalized professional procedure. Based on these findings, a guideline for professionals, which support foster parents and children during this transition process, has been developed. It serves as a compass, guidance, and mentoring process that requires systematic attention to relevant topics and issues that includes all kind of administrative tasks as well as emotional aspects such as important learning/unlearning processes (letting go of the parents, and coping strategies).

\section{Reflection}

Practice-based research as an approach to gain new knowledge, carried out by practitioners and researchers in a heterarchical process, and the outcomes of that theory-practice project, has enabled the development of new working tools, such as a guideline. As a next step, the research-based guideline is now implemented and to be tested by select practising social workers and then optimized by the project team. The aim is to enhance the tool and to provide the instrument in future to all relevant professionals.

Our study demonstrates that practice-based research is an innovative and successful approach to search for new understandings and to seek out new working tools improving and facilitating day-to-day application of professional processes. However, this kind of research is more directed towards particular 
goals rather than generating knowledge in a broad sense. Munsch (2012, p. 1181) argues that the critical point is the motivation and willingness of practitioners to cooperate with researchers. For this reason, questions, interests, and aims of the study have to be defined in a participatory process with all key-stakeholders. This heterarchical collaboration may end in misguided loyalty - on the part of the researchers. This may lead to an increased risk of a concealment of certain issues of a project in its reports, which makes the findings barely useful for other projects (Munsch, 2012, p. 1181). Nevertheless, positive aspects of this kind of research projects, as they appear in literature, have been particularly shown in the present study. This includes the specialized knowledge of the practitioners and relevant interest groups as well as their network might be used for sampling. Furthermore, their widespread network enables them to share the findings and the particular outcome with a wider professional community. Therefore, a key element of theory-practice projects is the transferability of the understandings reached as a result of the research process.

\section{References}

Aebischer, M. und Gabriel, T. (2013). Einleitung. In Integras, Fachverband Sozial- und Sonderpädagogik (Hrsg.), Leitfaden Fremdplatzierung(S. 7 - 9). Zürich: Integras.

Gabriel, T. \&Stohler, R. (2008). Switzerland. In M. Stein \& E.R.

Munro (Ed.), Young People's Transitions from Care to Adulthood. International Research and Practice, (pp. 197 - 208). London: Jessica Kingsley Publishers.

Gassmann, Y. (2010). Pflegeeltern und ihre Kinder. Empirische Analysen von Entwicklungsverläufen und Ressourcen im Beziehungsgeflecht. Münster: Waxmann.

Jespersen, A. (2011). Belastungen und Ressourcen von Pflegeeltern. Analyse eines Pflegeeltern-Onlineforums. Siegen: Zentrum für Planung und Evaluation Sozialer Dienste.

Munsch, C. (2012). Praxisforschung in der Sozialen Arbeit. In W. Thole (Hrsg.), Grundriss Soziale Arbeit, (S. 1177 - 1189). Wiesbaden: VS Verlag für Sozialwissenschaften. 
Nowotny, H, Scott, P. \& Gibbons, M. (2001). Re-thinking Science Knowledge and the Public in an Age of Uncertainty. Cambridge: Polity Press.

Schröer, W. \& Thomas, S. (2014). Das Ende der Vollzeitpflege. In A. Kuhls, J. Glaum\& W. Schröer (Hrsg.), Pflegekinderhilfe im Aufbruch. Aktuelle Entwicklungen und neue Herausforderungen in der Vollzeitpflege (S. 174 - 184). Weinheim: Beltz Juventa.

Stein, M. \& Munro, E.R. (Eds.). (2008).Young People's Transitions from Care to Adulthood. International Research and Practice. London: Jessica Kingsley Publishers.

SWPI (2010). Evidence Based Practice. Retrieved February 17, 2015, from http://www.socialworkpolicy.org/research/evidencebased-practice-2.html

Uggerhøj, L. (2011).What is Practice Research in Social Work Definitions, Barriers and Possibilities. In Social Work and Society, International Online Journal, Vol 9(1). Retrieved February 17, 2015 from http:/ / www.socwork.net/sws/article/view/6/22

Zatti, K.B. (2005). Das Pflegkinderwesen in der Schweiz. Analyse, Qualitätsentwicklung und Professionalisierung. Expertenbericht im Auftrag des Bundesamtes für Justiz. 